\title{
Retrospective Analysis of Management of Ingested Foreign Bodies in Emergency Department
}

\author{
Rezan Karaali' (iD , Ahmet Kayalı' ${ }^{1}$ (iD , 0sman Sezer Çınaroğlu' ${ }^{1}$ (iD \\ Zeynep Karakaya ${ }^{1}$ (D) , Firdevs Topal ${ }^{2}$ (iD
}

'İzmir Katip Çelebi Üniversitesi Atatürk Eğitim ve Araştırma Hastanesi, Acil Tıp, Karabağlar, Türkiye

${ }^{2}$ Izmir Katip Çelebi Üniversitesi Atatürk Eğitim ve Araştırma Hastanesi, Gastroenteroloji, Karabağlar, Türkiye

Rezan KARAALI, M.D.

Ahmet KAYALI, Asst. Prof. Dr.

Osman Sezer ÇINAROĞLU, M.D.

Zeynep KARAKAYA, Assoc. Prof. Dr. Firdevs TOPAL, Prof. Dr.

Correspondence: Rezan Karaali İzmir Katip Çelebi Üniversitesi Atatürk Eğitim ve Araştırma Hastanesi, Acil Tıp, Karabağlar, Türkiye

Phone: +905052681673

E-mail: rezantahtaci@hotmail.com

\section{ABSTRACT}

Purpose: A foreign body in the airway or gastrointestinal system is a common cause of emergency presentations in adults.

Patients and Methods: This single center, retrospective study involved patients presenting to a tertiary emergency department with foreign bodies in the airway or gastrointestinal system. Non-traumatic, non-pregnant patients aged 18 or over were scanned through the ICD-10 diagnostic code. Age and sex, reasons for ingestion/insert on (unintentional, for suicide, or for sexual gratification), the type of object, test data, treatment, complications and mortality were recorded.

Results: The mean age of the 189 patients included was 36 , and $59.2 \%$ were women. Ingest on was unintentional in $86.2 \%$, for suicide in $10.6 \%$, and for sexual gratification in $3.2 \%$. Unintentional ingestion was more common in women, while ingestion for self-harm was unique to men. Fish bones, pins, garlic, and teeth were most frequently encountered in unintentional ingestions. The most commonly ingested objects for self-harm were sharp items such as razor blades and nails. Flexible laryngoscopy was employed in $40.7 \%$ of cases and endoscopic interventions in $57.6 \%$. Foreign bodies were removed with flexible laryngoscopy or endoscopy in $61.3 \%$ of cases, and surgery was performed on $6.9 \%$. Foreign bodies were most encountered in the larynx-pharynx, esophagus, and stomach.None of the patients died. No complications were detected.

Conclusion: Foreign body ingestion is a widespread, global clinical problem. Our hospital receives many presentations involving foreign body ingestion, and the emergency and gastroenterology departments have considerable experience in this area. The endoscopic approach was the safest and most effective method due to its high success and low complication rates.

Keywords: Emergency department, foreign body, diagnose, emergency management

\section{Yabancı Cisim Alımı ile Acil Servise Başvuran Hastaların Retrospektif Değerlendirilmesi ÖZET}

Amaç: Beslenme ya da solunum yolunda yabancı cisim olması erişkinlerde acil başvurularının sık bir nedenidir.

Hastalar ve Yöntem: Bu çalışma 3. Basamak acil servise başvuran hastalarla, tek merkezli, retrospektif olarak yapııdı.18 yaş üzeri, gebe olmayan, travması olmayan ve dosyalarında yeterli veriye ulaşılabilen hastalar çalışmaya alındı. Hastaların yaşı, cinsiyeti, alımın nedeni (yanlışlıkla, suicid amaçlı, cinsel amaçı), cismin türü, yapılan tetkikler, uygulanan tedavi yöntemi, komplikasyon ve mortalite durumu kaydedildi.

Bulgular: Çalışmaya alınan 189 hastanın yaş ortalaması 36, hastaların \% 59,2'si kadın olarak bulundu. Hastaların \% 86,2'si yanlışııkla, \%10,6'sı suicidal amaçlı ve \%3,2'si cinsel amaçı almıştı. Yanlışlıkla alımlar kadınlarda fazla saptanırken, self harm amaçı alımlara sadece erkeklerde rastlandı. Yanlışı̌kla alımlarda en fazla kılçık, iğne, gıda, sarımsak ve dişe rastlandı. Self harm amaçlı alımlarda en fazla kullanılan maddeler jilet, çivi gibi keskin cisimlerdi. Olguların \%40,7'sine fleksible laringoskopi, \%57,6'sına endoskopik girişim yapıldı. \%61,3'ünden yabancı cisim fleksible laringoskopi ve endoskopik girişim ile çıkarılırken; \%6,9'una cerrahi işlem yapıldı. Yabancı cisimlerin en sık rastlandığı yerler ise larenks- farenks, ösefagus ve mide olarak bulundu. Komplikasyona rastlanmadı. Hastalardan hiçbiri ölmedi.

Sonuç: Yabancı cisimlerin yutulması dünya çapında yaygın bir klinik problemdir. Hastanemize yabancı cisim yutulma şikayetiyle başvuruların çok olması nedeniyle acil servis ve gastroentereoloji klinikleri bu konuda tecrübeli ve deneyimlidir. Çalışmamızın sonucunda, yüksek başarı ve düşük komplikasyon oranı nedeniyle endoskopik yaklaşım en güvenilir ve efektif yöntem olarak değerlendirilmiştir.

Anahtar Sözcükler : Acil servis, yabancı cisim, tanı, acil yaklaşım. 
oreign body ingestion or aspiration is frequently encountered in the pediatric age group. Unintentional ingestion may be seen in mentally disabled or substance-addicted adult patients, while numerous foreign bodies may be ingested for purposes of suicide among individuals with psychiatric disorders $(1,2)$. Unintentionally ingested bodies frequently include pins, toothpicks, fish and chicken bones. Obstructions may also occur during consumption of normal foods or large morsels among adults with physiological narrowing or stricture resulting after surgery $(3,4)$. The annual reported mortality rate among adults in the USA is approximately 1500 . Eighty to ninety percent of foreign bodies are expelled spontaneously from the body, while $10-20 \%$ can be removed with endoscopy, and $1 \%$ require surgery (3-6). The factors determining the emergency approach adopted are the type of body, whether it is sharp or pointed, its location, and the patient's symptoms. The complication rate is less than $1 \%$. These may include gastrointestinal bleeding, perforation, fistula development, and intra-abdominal abscess $(1,4)$. It is important for the patient to be well examined and for treatment to be well managed.

The purpose of this study was to describe our emergency approach in patients presenting to the emergency department of a tertiary hospital due to foreign body ingestion, aspiration, or insertion, together with the outcomes.

\section{MATERIAL AND METHOD}

The study commenced following receipt of ethical committee approval (No. 2019GOKAE-1360 dated 21.01.2010).

\section{Patient selection}

Patients presenting to the emergency department of a tertiary hospital in Turkey between 01.10.2014 and 01.10.2019 due to foreign body ingestion or aspiration were scanned retrospectively from the hospital automation system using the ICD-10 diagnostic code. Nonpregnant and non-traumatic patients aged over 18 and with sufficient data available in their records were included.

\section{Data collection}

Patients' age and sex were recorded, together with reasons for ingestion (unintentional, for purposes of suicide, or sexual gratification), the type of object, test data, the treatment applied, complications and mortality.

\section{Statistical analysis}

Data were analyzed on IBM Statistics Version 24.00 software. For the descriptive quantitative variables, the mean, standard deviation, median, IQR, the largest and the smallest value are given. Number and percentage values are given for qualitative variables. Descriptive data were given in numbers of cases, \% and median (IQR). The distribution of continuous variables was examined using the Kolmogorov Smirnov test. Mann-Whitney $U$ statistical analysis was applied to compare continuous data between two groups. $p$ values $<0.05$ were considered statistically significant.

\section{RESULTS}

One hundred eighty-nine patients with a mean age of 36 (26) years were included. Women constituted $59.2 \%$ of patients, with a mean age of 39 (27), while the mean age of the male patients was 31 (25). No statistically significant difference was determined between the sexes (Table 1).

\begin{tabular}{|c|c|c|c|}
\hline \multicolumn{3}{|c|}{ Table 1. Cases' mean age and distributions by gender } \\
\hline Sex & Mean (IQR) & $\begin{array}{c}\text { Minimum- } \\
\text { Maximum }\end{array}$ & \multirow{2}{*}{ p $^{*}$} \\
\hline Male & $31(25)$ & $17-74$ & \multirow{2}{*}{.017} \\
\hline Female & $39(27)$ & $18-81$ & \\
\hline Total & $36(26)$ & $17-81$ & \\
\hline *: using the t test \\
\hline
\end{tabular}

The nature of foreign body ingestion/insertion was also examined. Ingestion was unintentional in $86.2 \%(n=163)$ of the 189 patients and for purposes of suicide in $10.6 \%$ $(n=20)$, while insertion for sexual gratification was observed in $3.2 \%(n=6)$. Analysis by gender revealed that ingestion for suicidal purposes was solely among men, that insertion for sexual gratification was more common among men, and that unintentional ingestion was more common among women. Ingestion for suicidal purposes was significantly higher in men, while unintentional ingestion was significantly higher among women $\left(\mathrm{p}_{\text {suicide }}<0.001\right.$ and $\left.\mathrm{p}_{\text {unintentional }}<0.001\right)$. No difference was observed between the sexes in terms of insertion for sexual gratification ( $p>0.05)$.

Foreign bodies were most commonly detected in the larynx in both men and women. No significant relationship was observed between gender and foreign body location. 
Intervention involved flexible laryngoscopy in $40.7 \%$ of cases $(n=77)$ and endoscopy in $57.6 \%(n=109)$. No significant association was observed between gender and endoscopic intervention and flexible laryngoscopy. Following these procedures, the foreign body was removed with flexible laryngoscopy and endoscopic intervention in $61.3 \%(n=116)$ of cases, while surgery was required for removal in $6.9 \%(n=13)$. The incidence of foreign body removal with endoscopic intervention or flexible laryngoscopy was statistically significantly higher in males $(p=0.023)$.

Recurrence of foreign body ingestion was observed in $12.7 \%$ of male cases and $2.5 \%$ of female cases. This was statistically significant $(p=0.013)$.

Foreign bodies were detected using $\mathrm{x}$-rays in $30.7 \%$ of cases $(n=58)$, while cross-sectional imaging was employed in $16.9 \%(n=32)$. Foreign bodies were determined using $x$-ray in $36.4 \%(n=40)$ of men and in $22.8 \%(n=18)$ of women. This difference was statistically significant $(p=0.046)$. No gender difference was observed in terms of crosssectional imaging requirements (Table 2 ).

When cases were differentiated based on the radio-opacity of the foreign bodies involved, and visibility on x-ray was evaluated, $98.3 \%$ of visualized foreign bodies were radio-opaque. In addition, $37.4 \%(n=49)$ of substances that were not visible on $x$-ray were radio-opaque, $33.6 \%$ $(n=44)$ were not radio-opaque, and the foreign body could not be detected in $29 \%$ ( $n=38$ ) of cases.

Flexible laryngoscopy was employed for foreign body extraction in $40.7 \%$ ( $n=77)$ of cases, and the foreign body was removed in $36.4 \%$ ( $n=29)$ of cases undergoing the procedure. Endoscopic procedures were performed on 55.7\% $(n=109)$ of the 189 cases, the bodies being extracted in $81.7 \%$ of cases undergoing the procedure.

None of the patients died. No complications were detected.
Table 2. Distribution of foreign body removal methods and locations by gender

\begin{tabular}{|c|c|c|c|c|c|}
\hline \multirow[b]{2}{*}{ Parameter } & \multirow{2}{*}{$\begin{array}{l}\text { Sub- } \\
\text { Parameter }\end{array}$} & \multicolumn{3}{|c|}{ Sex } & \multirow[b]{2}{*}{$p$} \\
\hline & & $\begin{array}{l}\text { Female } \\
\mathrm{n}(\%)\end{array}$ & $\begin{array}{l}\text { Male } \\
\mathrm{n}(\%)\end{array}$ & $\begin{array}{l}\text { Total } \\
\mathrm{n}(\%) \\
\end{array}$ & \\
\hline \multirow{2}{*}{ Suicide status } & $\begin{array}{l}\text { Not for } \\
\text { suicidal } \\
\text { purposes }\end{array}$ & $\begin{array}{c}79 \\
(100.0)\end{array}$ & $\begin{array}{c}90 \\
(81.8)\end{array}$ & $\begin{array}{c}169 \\
(59.4)\end{array}$ & \multirow{2}{*}{$<0.001^{*}$} \\
\hline & $\begin{array}{l}\text { For suicidal } \\
\text { purposes }\end{array}$ & $0(0.0)$ & $\begin{array}{c}20 \\
(18.29\end{array}$ & $\begin{array}{c}20 \\
(10.6)\end{array}$ & \\
\hline \multirow{2}{*}{$\begin{array}{l}\text { Unintentional } \\
\text { ingestion/ } \\
\text { aspiration }\end{array}$} & Intentional & $1(1.3)$ & $\begin{array}{c}25 \\
(22.7)\end{array}$ & $\begin{array}{c}26 \\
(13.8)\end{array}$ & \multirow{2}{*}{$<0.001^{*}$} \\
\hline & Unintentional & $\begin{array}{c}78 \\
(98.7)\end{array}$ & $\begin{array}{c}85 \\
(77.3)\end{array}$ & $\begin{array}{c}163 \\
(86.2)\end{array}$ & \\
\hline \multirow{2}{*}{$\begin{array}{l}\text { Sexual } \\
\text { gratification }\end{array}$} & $\begin{array}{l}\text { Not for sexual } \\
\text { gratification }\end{array}$ & $\begin{array}{c}78 \\
(98.7)\end{array}$ & $\begin{array}{c}105 \\
(95.5)\end{array}$ & $\begin{array}{c}183 \\
(96.8)\end{array}$ & \multirow{2}{*}{$.202^{* *}$} \\
\hline & $\begin{array}{l}\text { For sexual } \\
\text { gratification }\end{array}$ & $1(1.3)$ & $5(4.5)$ & $6(3.2)$ & \\
\hline \multirow{7}{*}{$\begin{array}{l}\text { Location of } \\
\text { foreign body }\end{array}$} & Esophagus & $\begin{array}{c}23 \\
(29.1)\end{array}$ & $\begin{array}{c}31 \\
(19.1)\end{array}$ & $\begin{array}{c}44 \\
(23.3)\end{array}$ & \multirow{7}{*}{$.517^{* *}$} \\
\hline & Larynx & $\begin{array}{c}31 \\
(39.2)\end{array}$ & $\begin{array}{c}40 \\
(36.4)\end{array}$ & $\begin{array}{c}71 \\
(37.6)\end{array}$ & \\
\hline & Stomach & $\begin{array}{c}14 \\
(17.7)\end{array}$ & $\begin{array}{c}29 \\
(26.4)\end{array}$ & $\begin{array}{c}43 \\
(22.8)\end{array}$ & \\
\hline & Small Bowel & $6(7.6)$ & $9(8.2)$ & $15(7.9)$ & \\
\hline & Large Bowel & $1(1.3)$ & $3(2.7)$ & $4(2.1)$ & \\
\hline & Rectum-Anus & $2(2.5)$ & $6(5.5)$ & $8(4.2)$ & \\
\hline & Cecum & $2(2.5)$ & $2(1.8)$ & $4(2.1)$ & \\
\hline \multirow{2}{*}{$\begin{array}{l}\text { Flexible } \\
\text { laryngoscopy }\end{array}$} & $\begin{array}{l}\text { Not } \\
\text { performed }\end{array}$ & $\begin{array}{c}45 \\
(57.0)\end{array}$ & $\begin{array}{c}67 \\
(60.9)\end{array}$ & $\begin{array}{c}112 \\
(59.3)\end{array}$ & \multirow{2}{*}{$.586^{*}$} \\
\hline & Performed & $\begin{array}{c}34 \\
(43.0)\end{array}$ & $\begin{array}{c}43 \\
(39.1)\end{array}$ & $\begin{array}{c}77 \\
(40.7)\end{array}$ & \\
\hline \multirow{2}{*}{$\begin{array}{l}\text { Endoscopic } \\
\text { intervention }\end{array}$} & $\begin{array}{l}\text { Not } \\
\text { performed }\end{array}$ & $\begin{array}{c}35 \\
(44.39\end{array}$ & $\begin{array}{c}45 \\
(40.9)\end{array}$ & $\begin{array}{c}80 \\
(42.39\end{array}$ & \multirow{2}{*}{$.641^{*}$} \\
\hline & Performed & $\begin{array}{c}44 \\
(55.7)\end{array}$ & $\begin{array}{c}65 \\
(59.1)\end{array}$ & $\begin{array}{c}109 \\
(57.7)\end{array}$ & \\
\hline \multirow{2}{*}{$\begin{array}{l}\text { Foreign body } \\
\text { removal }\end{array}$} & Not extracted & $\begin{array}{c}38 \\
(48.1)\end{array}$ & $\begin{array}{c}35 \\
(31.8)\end{array}$ & $\begin{array}{c}73 \\
(38.6)\end{array}$ & \multirow{2}{*}{.023} \\
\hline & Extracted & $\begin{array}{c}41 \\
(51.9)\end{array}$ & $\begin{array}{c}75 \\
(68.2)\end{array}$ & $\begin{array}{l}116 \\
(61.4)\end{array}$ & \\
\hline \multirow[t]{2}{*}{ Surgery } & $\begin{array}{l}\text { Not } \\
\text { performed }\end{array}$ & $\begin{array}{c}73 \\
(92.4)\end{array}$ & $\begin{array}{c}103 \\
(93.6)\end{array}$ & $\begin{array}{c}176 \\
(93.1)\end{array}$ & \multirow[t]{2}{*}{$.741^{*}$} \\
\hline & Performed & $6(7.6)$ & $7(6.4)$ & $13(6.9)$ & \\
\hline \multirow{2}{*}{ Recurrence } & No recurrence & $\begin{array}{c}77 \\
(97.5)\end{array}$ & $\begin{array}{c}96 \\
(87.3)\end{array}$ & $\begin{array}{l}173 \\
(91.5)\end{array}$ & \multirow{2}{*}{$.013^{*}$} \\
\hline & $\begin{array}{l}\text { Recurrence } \\
\text { occurred }\end{array}$ & $2(2.5)$ & $\begin{array}{c}14 \\
(12.7)\end{array}$ & $16(8.5)$ & \\
\hline \multirow{2}{*}{$\begin{array}{l}\text { Detection } \\
\text { with } x \text {-ray } \\
\text { imaging }\end{array}$} & Not detected & $\begin{array}{c}61 \\
(77.2)\end{array}$ & $\begin{array}{c}70 \\
(63.6)\end{array}$ & $\begin{array}{c}131 \\
(69.3)\end{array}$ & \multirow{2}{*}{$.046^{*}$} \\
\hline & Detected & $\begin{array}{c}18 \\
(22.8)\end{array}$ & $\begin{array}{c}40 \\
(36.4)\end{array}$ & $\begin{array}{c}58 \\
(30.7)\end{array}$ & \\
\hline \multirow{2}{*}{$\begin{array}{l}\text { Tomography } \\
\text { and } \\
\text { visualization } \\
\text { status }\end{array}$} & Not visualized & $\begin{array}{c}66 \\
(83.5)\end{array}$ & $\begin{array}{c}91 \\
(82.7)\end{array}$ & $\begin{array}{c}157 \\
(83.1)\end{array}$ & \multirow{2}{*}{$.883^{*}$} \\
\hline & Visualized & $\begin{array}{c}13 \\
(16.5)\end{array}$ & $\begin{array}{c}19 \\
(17.3)\end{array}$ & $\begin{array}{c}32 \\
(16.9)\end{array}$ & \\
\hline
\end{tabular}




\section{DISCUSSION}

Foreign body ingestion or aspiration in adults frequently assumes the form of attempting to swallow large pieces of food or of normal-sized pieces becoming trapped due to physiological or pathological narrowing. Deliberate ingestion for purposes of self-harm among patients with psychiatric disorders or with secondary objectives, such as imprisoned individuals, is also seen among adult patients. Adult studies have reported a mean age of 50-53 years (7). The mean age in the present study was 31-33 years.

Although unintentional ingestion or aspiration is more common in the pediatric age group, previous studies have also reported it in the adult age group. Li et al. and Okan et al. both reported adult patients presenting due to unintentional foreign body ingestion. Food bolus impaction was most frequently determined in these studies $(8,9)$. Unintentional pin ingestion was also observed in Kızıltan et al.'s report concerning seven patients with indications for surgery (4). The most commonly ingested objects in Hong et al.'s study were fish bones, medications, shells, and meat (1). In the present study, unintentional ingestion most commonly involved fish bones, pins, foodstuffs garlic, and teeth. Fish bones being the most frequently ingested items are expected findings since the city where the study was performed is a coastal one and fish consumption rates are high. One reason for the greater incidence of unintentional ingestion in women than in men may be related to the use of headscarves among women in Turkey, and to pins intended for attaching headscarves being held in the mouth before use.

Although unintentional ingestion was more common among women, ingestion for purposes of self-harm was observed only among men. The objects most frequently ingested for purposes of self-harm were sharp objects such as razor blades and nails. Ingestion for self-harm generally involves the swallowing of numerous, large sharp/pointed objects. Ninety-two percent of the patients in Palta et al.'s study had swallowed objects such as toothbrushes, pens, and forks for purposes of self-harm (6). Sharp objects were found in all patients with ingestions intended for self-harm in Robertson et al.'s study (10). Due to the prevalence of ingestions for purposes of self-harm, the European Society of Gastrointestinal Endoscopy (ESGE) produced a separate heading for these patients. Since a secondary aim is usually present in recurring presentations involving ingestions of numerous sharp objects ingested for purposes of self-harm, the ESGE recommends that hospitalization of these patients be kept as short as possible by doing endoscopy quickly. Psychiatric consultations are essential, and patients without indications for hospitalization must be discharged as quickly as possible (5). Since sharp and pointed objects were detected in patients ingesting for self-harm in the present study, these all underwent esophagogastroduodenoscopy (EGD), and psychiatric consultations were requested. Our approach to these patients was consistent with the guideline recommendations.

Foreign bodies are also inserted via the anal route for sexual gratification. According to Coşkun et al., Yıldız et al., Principe et al., and the ESGE, this is more frequent in the male gender $(5,11-13)$. No difference was observed between male and female gender in terms of insertion for sexual gratification in the present study. This may be attributed to the low number of such patients (six patients).

In terms of the locations of foreign bodies, in the present study, these were most commonly detected in the larynxpharynx, the esophagus, and the stomach. No significant difference was observed between men and women in terms of foreign body locations. This is because the location of the foreign body largely depends on its shape and size. Geraci et al, reported food bolus impaction involving fish and other small bones frequently in the pharynx (7). Hong et al. most frequently observed objects in the esophagus, and $\mathrm{Li}$ et al. in the esophagus and stomach $(1,8)$. Since large and sharp objects are generally employed ingestions intended for self-harm, these are frequently detected in the stomach and duodenum (6). Consistent with previous studies, objects inserted for sexual gratification were detected in the rectum (11-13).

Recommendations also exist concerning the imaging methods to be employed in cases presenting due to foreign body ingestion. According to the ESGE, the decision should depend on whether or not the object is radio-opaque. Patients can thus be protected against unnecessary radiation exposure, and other definite diagnostic methods can be applied sooner. X-ray is not recommended in case of fish or other small bones, or small metal objects (5). In the present study, X-rays were taken for every patient presenting to the emergency department. However, $46 \%$ of radio-opaque objects could not be visualized on X-ray. Advanced tests may be recommended when objects cannot be determined on $X$-ray due to low sensitivity. Imaging is important in terms of determining the optimal form of treatment and, as emphasized by the ESGE, the most appropriate imaging technique must be selected based 
on the type of object involved and the patient's condition. Asymptomatic patients must be taken for follow-up in the presence of blunt objects not causing an obstruction. Therapeutic EGD must be performed within two hours in case of sharp objects and/or objects causing obstruction in the esophagus. In case of objects that have passed the stomach, EGD is recommended within 24-h in the presence of sharp objects, magnets, batteries, and large objects, and within 72-h in case of medium-sized blunt objects (5).

The type of treatment administered in our patient group was also selected based on the type and location of the object in the question, although the rate of EGD was higher than recommended and higher than that in other studies. Since our hospital provides a 24-h endoscopy service and receives referrals from external centers, patients undergoing EGD and being discharged from the emergency department, rather than being admitted to the emergency department or the ward, provided a significant advantage in terms of patient comfort and shortening the length of hospital stay. No patients in the present study were hospitalized apart from those with indications for surgery, and no complications developed after EGD. Our complication rate was low compared to other studies involving EGD in the approach to foreign bodies $(1,6,7)$. One advantage of EGD being performed on all patients in Li et al.'s study was that new diseases involving the gastrointestinal system were detected, and the therapeutic process was also initiated for these (8). EGD is therefore a useful therapeutic technique in terms of removal of foreign bodies and also due to its ability to detect incidental diseases.

\section{LIMITATIONS}

The principal limitations of this study were its retrospective and single-center nature.

\section{CONCLUSION}

In conclusion, foreign body ingestion is a widespread and global clinical problem. Due to the large number of presentations involving foreign body ingestions received by our hospital, our emergency department and gastroenterology clinic have significant experience on this subject. Our study indicates that due to its high success and low complication rates, the endoscopic approach is the most effective and reliable method in such cases.

\section{REFERENCES}

1- Hong KH, Kim YJ, Kim JH, Chun SW, Kim HM, Cho JH Risk Factors For Complications Associated With Upper Gastrointestinal Foreign Bodies. World J Gastroenterol 2015;21(26):8125-31.

2- Choi PW, Surgical Removal of Multiple Gastric Foreign Bodies. Case Report. American Journal of Medical Case Reports 2019;7(1):1-4.

3- Nicolodi GC, Trippia CR,. Caboclo MFFS, de Castro FG, Miller WP, de Lima RR et al. Intestinal Perforation By An Ingested Foreign Body. Radiol Bras 2016;49(5):295-9.

4- Kızıltan R, Yılmaz Ö, Aras A, Toktaş O, Batur A, Ağar F et al. Ingested Intraabdominal Foreign Bodies That Require Surgical Intervention. Ulus Travma Acil Cerrahi Derg 2016;22(3):269-272.

5- Birk M, Bauerfeind P, Deprez PH, Häfner M, Hartmann D, Hassan C et al. Removal Of Foreign Bodies in The Upper Gastrointestinal Tract in Adults: European Society of Gastrointestinal Endoscopy (ESGE) Clinical Guideline. Endoscopy 2016; 48: 489-96

6- Palta R, Sahota A, Bemarki A, Salama P, Simpson N, Laine L. Foreign-Body Ingestion: Characteristics And Outcomes in A Lower Socioeconomic Population With Predominantly Intentional Ingestion. Gastrointestinal Endoscopy 2009;69(3):1-2.

7- Geraci G , Sciume C, Di Carlo G, Picciurro A, Modica G. Retrospective Analysis Of Management Of Ingested Foreign Bodies And Food Impactions in Emergency Endoscopic Setting in Adults. BMC Emergency Medicine 2016;16:42.

8- Li ZS, Sun ZX, Zou DW, Xu GM, Wu RP, Liao Z. Endoscopic Management Of Foreign Bodies in The Upper-GI Tract: Experience With 1088 Cases in China. Gastrointestinal Endoscopy. 2006;64(4): 485-92.

9- Okan I, Akbaş A, Küpeli M, Yeniova AÖ, Esen M, Özsoy Z. Management Of Foreign Body Ingestion And Food Impaction in Adults: A CrossSectional Study. Ulus Travma Acil Cerrahi Derg 2019;25(2):159-66.

10- Robertson AR. Self-harm by Sharp Foreign Body Ingestion. Suicide Life Threat Behav 2019;49(3):735-8.

11- Coskun A, Erkan N, Yakan S, Yıldirim M, Cengiz F. Management of rectal foreign bodies. World Journal of Emergency Surgery 2013; $8(11): 2-5$.

12- Yildiz SY, Kendirci M, Akbulut S, Ciftci A, Turgut HT, Hengirmen S. Colorectal Emergencies Associated With Penetrating Or Retained Foreign Bodies. World Journal of Emergency Surgery 2013; 8(25):2-5.

13- Principe DR, Rubin J, Narbutis M, Cabrera J ,Mitsiev I. Repeat Presentation Of Large Rectal Foreign Body Requiring Surgical Intervention. Journal of Surgical Case Reports 2019;4:1-3. 